IZA DP No. 4817

Growth, History, or Institutions?

What Explains State Fragility in Sub-Saharan Africa

Graziella Bertocchi

Andrea Guerzoni

March 2010 


\title{
Growth, History, or Institutions? What Explains State Fragility in Sub-Saharan Africa
}

\author{
Graziella Bertocchi \\ University of Modena and Reggio Emilia, \\ RECent, CEPR, CHILD and IZA \\ Andrea Guerzoni \\ University of Modena and Reggio Emilia
}
Discussion Paper No. 4817
March 2010

\author{
IZA \\ P.O. Box 7240 \\ 53072 Bonn \\ Germany \\ Phone: +49-228-3894-0 \\ Fax: +49-228-3894-180 \\ E-mail: iza@iza.org
}

\begin{abstract}
Any opinions expressed here are those of the author(s) and not those of IZA. Research published in this series may include views on policy, but the institute itself takes no institutional policy positions.

The Institute for the Study of Labor (IZA) in Bonn is a local and virtual international research center and a place of communication between science, politics and business. IZA is an independent nonprofit organization supported by Deutsche Post Foundation. The center is associated with the University of Bonn and offers a stimulating research environment through its international network, workshops and conferences, data service, project support, research visits and doctoral program. IZA engages in (i) original and internationally competitive research in all fields of labor economics, (ii) development of policy concepts, and (iii) dissemination of research results and concepts to the interested public.
\end{abstract}

IZA Discussion Papers often represent preliminary work and are circulated to encourage discussion. Citation of such a paper should account for its provisional character. A revised version may be available directly from the author. 
IZA Discussion Paper No. 4817

March 2010

\section{ABSTRACT \\ Growth, History, or Institutions? What Explains State Fragility in Sub-Saharan Africa}

We explore the determinants of state fragility in sub-Saharan Africa. Controlling for a wide range of economic, demographic, geographic and istitutional regressors, we find that institutions, and in particular the civil liberties index and the number of revolutions, are the main determinants of fragility, even taking into account their potential endogeneity. Economic factors such as income growth and investment display a non robust impact after controlling for omitted variables and reverse causality. Colonial variables reflecting the history of the region display a marginal impact on fragility once institutions are accounted for.

JEL Classification: $\quad \mathrm{O} 43, \mathrm{H} 11, \mathrm{~N} 17$

Keywords: $\quad$ state fragility, Africa, institutions, colonial history

Corresponding author:

Graziella Bertocchi

University of Modena and Reggio Emilia

Viale Berengario 51

41100 Modena

Italy

E-mail: graziella.bertocchi@unimore.it 


\section{Introduction}

The concept of state fragility (from now on, fragility) has recently reached center stage in the debate on economic development, and in particular on the development prospects of sub-Saharan Africa (SSA). The concept of fragility has been associated with various combinations of the following dysfunctions: inability to provide basic services and meet vital needs, unstable and weak governance, a persistent condition of extreme poverty, lack of territorial control, and high propensity to conflict and civil war. The crucial relevance of fragility for SSA countries is motivated by the fact that they are overrepresented among fragile states, with drastic consequences on the eligibility of the region to substantial aid flows.

Several studies have examined the influence of the condition of fragility on development, either through its direct impact on income and growth, or through its indirect influence through aid allocation. In a growth regression framework, Bertocchi and Guerzoni (2010) find that for SSA a conventional definition of fragility is a not a significant covariate once standard regressors are accounted for. For a comparable sample, Baliamoune-Lutz (2009) shows that the impact of fragility on per capita income interacts with several other factors: in fragile countries, beyond a threshold level trade openness may actually be harmful to income, while small improvements in political institutions can have adverse effects. In Fosu (2009) the absence of policy syndromes encourages growth in SSA, but only one component of these syndromes, state breakdown, has to do with fragility. Burnside and Dollar (2000) provide evidence that aid is most effective in developing countries with sound institutions and policies, even if this conclusion is challenged by Hansen and Tarp (2001) and Dalgaard et al. (2004). McGillivray e Feeny (2008), for a world sample of fragile countries find that, while growth would have been slower in the absence of aid, at the same time these countries can only efficiently absorb a fraction of the aid flows. Finally, Chauvet e Collier (2007) analyze the preconditions for sustained policy turnarounds in failing states and show that 
financial aid can prolonge state failure, while aid through technical assistance can shorten it. Overall, a clear impact of fragility on economic outcomes has proved hard to assess. One possible explanation for the absence of a clear causal lin running from fragility to development is the endogeneity of fragility, or else the presence of a common third factor that determines both fragility and development itself.

The purpose of the present paper is to investigate the potential determinants of fragility, by explicitly taking into account its potential endogeneity with respect to other relevant economic and non-economic factors. We shall focus our attention on SSA, for two reasons. The first reason is that as previously explained this issue is particularly important for policy intervention in this region. The second reason is that fragility has proven such a multi-faceted issue that to concentrate on a specific, relatively homogeneous area may lead to more meaningful conclusions. At the same time, it is recognized that, especially within SSA, fragile states are sufficiently heterogeneous in terms of their economic, social, geographic and political characteristics. The European Report on Development (2009), which is entirely devoted to the problem of fragility in Africa, assembles a full array of stylized facts that confirms this heterogeneity.

The variables which we include in our investigation, as potentially relevant for Africa's economic and institutional performance, and therefore also for fragility in the region, are chosen among those which have been found relevant within the literature on growth and institutional development. We select a wide range of economic, demographic, geographic and istitutional regressors, following Bertocchi and Canova (2002), who assemble a dataset for Africa, in turn drawing on Barro (1991). We include, first of all, income and its growth rate. The only other empirical study on the determinants of fragility is Carment et al. (2008) who find, over a world sample, that per capita income level is the main factor, with higher income being associated to lower fragility. However, it should be kept in mind that the sign of tis effect is by no means mechanical since, especially in 
SSA, relatively wealthy societies have often been plagued by corruption and predation activities that can generate instability and dysfuntions, and thus increase fragility.

Without neglecting to control for additional economic and demographic factors, next we focus our attention on institutions. Non-quantitative studies in the field of political sciences and applied development have pointed to institutions as the central driver of fragility. Vallings and MorenoTorres (2005) argue that any other factor commonly associated with fragility is itself linked to weak institutions. For instance, while poverty is certainly linked to fragility, not all poor areas turn out to be fragile, since fragility occurs only when poverty is combined with the presence of a weak state that cannot manage manage effectively the causes and consequences of poverty itself. Therefore, we assess empirically the potential relevance of institutions.

In the literature on Africa, a lot of attention has been devoted to the role of history, and in particular of colonial history. Africa represents an appropriate setting for analyzing the impact of colonial rule because, historically, nowhere else was colonization so far-reaching as in the African experience that began at the end of the 19th century. There is a shared perception that fragility, as well as other dysfuntions such as corruption and ethnic conflict, might find its roots in the legacy of colonization. The European Development Report (2009) supports this perception by stressing the common characteristics of state formation in this region: its artificial character following decolonization, the extractive nature of colonial domination, the political and economic dependence from the metropolitan power, and the system of indirect rule. The literature on colonial influence has developed along two separate although complementary strands. One stresses the identity of the colonizers, while another points at the conditions in the colonies. Within the first strand, La Porta et al. (1998) have focused on the legal systems inherited by the colonies, Bertocchi and Canova (2002) on the nationality of the colonizers, Hall and Jones (1999) on the extent to which the primary languages of Western Europe are spoken as first languages today. Together with Landes (1998) and 
North et al. (1998), these contributions tend to agree on the conclusion that former British colonies inherited better institutions than the former colonies of France, Spain and Portugal. Within the second strand, Acemoglu et al. (2001) develop an alternative theory of institutional development which emphasizes the conditions in the colonies, and in particular settler mortality. The latter is employed as an instrument for current institutions, as measured by the risk of expropriation, in the effort to explain how institutions affect income. This approach is closely related to Engerman and Sokoloff (1997), who link institutions to factor endowments. Building on this literature, in order to investigate the historical determinants of fragility we exploit the information on colonization by introducing a number of colonial variables that reflect both the approaches described above: therefore, we evaluate the impact of the national identity of the colonizer (Britain vs. France vs. Portugal), the political status of the dominated countries (colonies vs. dependencies vs. independent countries), and settler mortality. Using this information, we follow two parallel empirical strategies. First, in an effort to alleviate the omitted variable problem, we include the colonial variables in an expanded list of possible determinants of fragility. Second, we try to exploit colonial history as a source of suitable instruments, in order to control for endogeneity.

In more detail, we organize our empirical investigation as follows. We consider a sample of 41 SSA countries. Our dependent variable is a dummy which takes value 1 is a country is fragile, 0 otherwise. While we have information on fragility only over the 1999-2007 period, we have earlier information for all our regressors. Therefore, to extend the period under consideration as much as possible, we organize our dataset as a panel over two subperiods, 1992-1999 and 2000-2007. The dependent variable reflects fragility in the final years of the subperiods, i.e., 1999 and 2007, while for the regressors we employ average values over the subperiods. Among economic factors, we consider per capita GDP (which we consider both in terms of levels and growth rates), investment, government expenditures, a measure of human capital given by primary enrollments, a measure of trade openness, and inflation. We also introduce demographic factors, namely, life expectancy and 
the fertility rate, as well as the index of ethnic fractionalization. Finally, to capture the quality of institutions, we select civil liberties and revolutions.

Our results can be summarized as follows. We find that institutional variables are the key determinants of fragility: the probability for a country to be fragile decreases with the level of civil liberties and increases with the number of revolutions. Economic determinants such as per capita GDP growth and investment, which show some explanatory power in pooled regressions, lose significance once we exploit the panel dimension of the dataset. Among our colonial variables, we find a mild positive impact only for British colonization, while French and Portuguese colonization, political status and settler mortality do not improve our understanding of the determinants of fragility, once standard contemporary measures of institutional quality are taken into account. Geography, as captured by latitude and a dummy for being landlocked, is equally insignificant. When we address the endogeneity problem we find that colonial variables are very weak instruments for all the potentially endogenous significant variables. Once we instrument them with their initial values, civil liberties and revolutions are confirmed once again as the only exogenous determinants of fragility. Finally, we also expand our perspective to the entire post-war period by reorganizing our data as a cross sectional dataset, where an average measure of fragility over 19992007 is regressed over average values of the regressors for 1960-1998. Over this longer run perspective, the impact of civil liberties becomes non-linear, with fragility being associated to extreme values of the index, while revolutions lose significance. Per capita income, on the other hand, appears to be positively associated with fragility, while colonial variables are unable to add explanatory power.

To sum up, after controlling for omitted variables and endogeneity, we find that institutions prevail on economic factors as the central drivers of fragility in Africa, confirming the intuition in Vallings and Moreno-Torres (2005). Whenever economic factors play a role, it often runs in the direction of 
making fragility more likely under good economic performances, contrary to what Carment et al. (2008) find for a world sample. Contrary to common perception, colonial history exerts a very marginal contribution to the determination of todays' fragility, with British colonies as the only significant variable.

The rest of the paper is organized as follows. Section 2 reports the definition of fragility and describes our dataset. Section 3 presents our empirical findings. Section 4 concludes and suggests directions for future research. The Data Appendix collects information about the data we employed.

2. Data

The concept of fragility is an elusive one. Failure, vulnerability and weakness have often been used as synonimous of fragility, by the Fund for Peace, the United States Agency for International Development, and the Brookings Institution, respectively. Fragility itself has been defined in several different manners by various international organizations. For example, the United Kingdom Department for International Development defines as fragile those states where the government cannot or will not deliver core functions to its people. According to the World Bank, fragile states are defined as low-income countries scoring 3.2 and below (over a 1-6 range) on the Country Policy and Institutional Assessment (CPIA). The OECD Development Assistance Committee (DAC) defines as fragile states those countries in the bottom two CPIA quintiles, as well as those which are not rated. ${ }^{1}$ Since CPIA ratings are publicly available only since 2005, for the purposes of our empirical investigation we use the OECD-DAC information about the distribution of the

\footnotetext{
${ }^{1}$ Other related indexes are the Failed State Index, the Index of State Weakness, the indicator of Failed \& Fragile States, and the Fragility States Index, respectively published by the Fund for Peace, the Brookings Institution, Country Indicators for Foreign Policy (CIFP), and Polity IV.
} 
International Development Association $\left(\right.$ IDA) ${ }^{2}$ member countries by CPIA quintiles, which is available from 1999 until 2007.

CPIA ratings are prepared annually by World Bank staff and are intended to capture the quality of a country's policies and institutional arrangements, with a focus on the key elements that are within the country's control, rather than on outcomes (such as growth rates) that are influenced by elements outside the country's control. Scores are assigned on the basis of 16 criteria (20 until 2003) which are grouped in four equally weighted clusters: Economic Management, Structural Policies, Policies for Social Inclusion and Equity, and Public Sector Management and Institutions. The ratings reflect a variety of indicators, observations, and judgments based on country knowledge, originated in the Bank or elsewhere, and on relevant publicly available indicators.

For our purposes, to refer to the CPIA ratings offers three advantages. First, the ratings have a crucial practical relevance, since they significantly influence the Bank’s concessional lending and grants allocated through the IDA according to a specific formula. Second, information on their distribution by quintiles is now available for a relatively extended time period, i.e., from 1999 to 2007. Third, because of their design, they do not reflect mechanically any of the variables we employ as regressors, so that they can safely be employed to define our dependent variable.

We construct a dataset including those 41 sub-Saharan countries for which we have information on the CPIA ratings distribution by quintiles. For these countries, we construct a fragility dummy variable, which takes value 1 if a country belongs to the bottom two CPIA quintiles or if it is not rated, 0 otherwise. The variables which we include as regressors are the following. Among economic factors, we consider per capita GDP (both in terms of levels and growth rates),

\footnotetext{
${ }^{2}$ IDA is the part of the World Bank that helps the world's poorest countries. Established in 1960, its aim is to reduce poverty by providing interest-free credits and grants. It currently represents one of the largest sources of assistance for the world's 79 poorest countries, 39 of which are in Africa.
} 
investment, government expenditures, a measure of human capital given by primary enrollments, a measure of trade openness, and inflation. For the variables listed so far, intuition may suggest that good economic performances, in all these dimensions, should reduce the likelihood of fragility. However, this intuition has actually been challenged in seveal contexts. We also introduce demographic factors, such as life expectancy and the fertility rate, as well as the index of ethnic fractionalization which, as suggested by work by Easterly and Levine (1997), could contribute to fragility. To capture the quality of institutions, we select the civil liberties index and the number of revolutions, even though we also consider alternatives such as political rights and three of the Kaufmann et al. (2009) governance indicators, namely government effectiveness, rule of law, and voice and accountability. To be noticed is that the civil liberties index is contructed in such a way that a higher value is associated with fewer civil liberties. The impact of civil liberties on fragility is a priori ambiguous: while on the one hand autocracies intrinsically feed fragility, on the other very liberal democracies may also prove to be vulnerable to political and economic disorder. Revolutions and other episodes of acute political unrest, on the other hand, are likely to represent a threat to stability, even though in principle that they could also represent a reaction to dysfunctions and thus a prelude to a new, more stable order. As in Bertocchi and Canova (2002), our colonial variables are the following: a set of dummies for British, French and Portuguese colonies, respectively, and a dummy capturing the political status during the colonial period, which takes value 2 for colonies, 1 for dependencies, and 0 for independent countries. In addition, from Acemoglu et al. (2001) we take settler mortality. Finally, our geographic variables are latitude and a dummy for being landlocked (see Sachs and Warner, 1997). More details are available in the Data Appendix.

For most of the empirical investigation, the available data are organized as a panel covering the 1992-2007 period and composed of two cross sections, over 1992-99 and 2000-07. The dependent variable is the fragility dummy in 1999 and 2007, i.e., in the final year of each cross section. For each regressor, we consider their average value in 1992-99 e 2000-07. This approach is meant to 
maximize the length of the period of observation, given the limited range of the information on fragility. By organizing the available data in this way, we were able to extend the investigation back to 1992, even though information on fragility is only available from 1999. Moreover, by treating as dependent variable fragility in the final year of each subperiods, we are able to mitigate the reverse causality problem running from fragility itself to the regressors. It has to be noticed, however, that data on some of the regressors are not available until 2007. Income data, for instance, are only available until 2004.

Table. 1 . Summary statistics

\begin{tabular}{|l|c|c|c|c|c|c|}
\hline \multicolumn{1}{|c|}{ Variable } & Obs. & Mean & Median & Min & Max & $\begin{array}{c}\text { Standard } \\
\text { deviation }\end{array}$ \\
\hline Fragility & 82 & 0.51 & 1 & 0 & 1 & 0.50 \\
pc GDP & 81 & 1438,19 & 1044,46 & 274,98 & 10118,06 & 1311,84 \\
pc GPD growth & 80 & 1.24 & 0.67 & -8.97 & 24.74 & 4.89 \\
Investment & 81 & 8.71 & 7.52 & 2.33 & 34.97 & 6.01 \\
Primary enrollment & 81 & 82.07 & 76.48 & 10.03 & 193.83 & 30.35 \\
Government expenditures & 81 & 24.51 & 21.37 & 2.60 & 85.59 & 13.79 \\
Trade & 81 & 67.66 & 58.69 & 2.02 & 181.18 & 35.84 \\
Inflation & 79 & 100.33 & 7.69 & 1.51 & 3945.13 & 492.29 \\
Life expectancy & 82 & 50.85 & 50.23 & 30.15 & 69.96 & 7.05 \\
Fertility rate & 82 & 5,72 & 5,77 & 3,68 & 7,72 & 0,94 \\
Ethnic fractionalization & 80 & 0.69 & 0.74 & 0.00 & 0.93 & 0.21 \\
Civil liberties & 82 & 4.57 & 4.56 & 1.38 & 7.00 & 1.26 \\
Revolutions & 82 & 0.30 & 0.00 & 0.00 & 1.33 & 0.39 \\
British Colony & 82 & 0.32 & 0 & 0 & 1 & 0.47 \\
French Colony & 82 & 0.39 & 0 & 0 & 1 & 0.49 \\
Portuguese Colony & 82 & 0.12 & 0 & 0 & 1 & 0.33 \\
Political status & 72 & 1.83 & 2 & 0 & 2 & 0.50 \\
Settler mortality & 50 & 544,36 & 280 & 26 & 2940 & 654,19 \\
Latitude & 82 & 10,53 & 10,40 & 0,42 & 29,69 & 6,38 \\
Landlock & 82 & 0.32 & 0 & 0 & 1 & 0.47 \\
Government effectiveness & 82 & 2.64 & 2.69 & 1.41 & 3.61 & 0.50 \\
Rule of law & 82 & 2.61 & 2.65 & 1.23 & 4.18 & 0.58 \\
Voice and accountability & 82 & 2.74 & 2.65 & 1.53 & 4.26 & 0.65 \\
\hline
\end{tabular}

Notes: Panet dataset. The panel is composed of two cross sections, over the 1992-99 and the 2000-07 subperiods.

Table 1 shows the descriptive statistics for the variables in our dataset. The (unreported) pairwise correlations among our variables show that fragility is highly correlated with civil liberties $(0,50)$ 
and revolutions $(0,44)$, while the correlation with economic variables is much lower (e.g., $-0,14$ with per capita GDP growth). The correlation coefficients between fragility and the Kauffman et al. (2009) indicators is very high but far from perfect (ranging between -0, 58 and -0, 71).

\section{Results}

\subsection{Basic specification}

Throughout subsections 3.1 to 3.3 , we perform our regression analysis on the panel dataset composed of two cross sections, for 1992-99 and 2000-07 respectively. The regressors are averages over the two subperiods of 1992-99 and 2000-07 and the dependent variable is the fragility dummy in 1999 and 2007. Because of the binary nature of the dependent variable, we start by running probit regressions with robust standard errors at the country level. The dependent variable has therefore to be interpreted as the probability that a country is fragile. Among the regressors, we include the main economic and institutional variables that have been found relevant in the literature on growth and institutions, whose potential role has been discussed in the previous section. Results are reported in Table 2, column 1, where we find that, among economic variables, the most significant one is GDP growth, which exerts a negative impact on the probability to be a fragile country. Investment is also marginally significant, with a somewhat surprising positive impact which may be attributed to an interaction between its effect and that of other covariates. ${ }^{3}$ The other economic and demographic variables we consider do not provide additional explanatory power to the regression. However, the two institutional variables are highly significant and with a positive

\footnotetext{
${ }^{3}$ An unreported variant of the same regression, which includes an interaction between investment and civil liberties, shows a negative marginal effect for investment and a positive one for the interaction, suggesting that the expected negative impact of investment on fragility may turn positive in countries with bad institutions, which are the majority in the sample. This non linear effect can be explained by the fact that conflict, corruption and predation activities may intensify in relatively wealthy societies, because of the resource curse.
} 
sign: namely, a higher value of the civil liberties index (i.e., more limited civil liberties) and a higher frequency of revolutions both make fragility more likely. An analogous regression including the square of civil liberties shows no evidence of a non linear impact and is therefore omitted in the following specifications. ${ }^{4}$

The results from the basic probit specification are also robust to an alternative pooled OLS estimation, presented in column 2, where GDP growth loses some of its significance. In columns 3 and 4 we exploit the panel dimension of the dataset, in order to control for the potential omission of variables through country and time effects. We opt for random effects at the country level since, given our limited sample size, fixed effects would induce a serious loss of degrees of freedom and the danger of multicollinearity. In column 3 the only two significant covariates are civil liberties and revolutions. The same results emerge in column 4 where time effects are also considered, i.e., where a period dummy is inserted to reflect the time series dimension of the sample. To be noticed is that the period dummy displays a positive and highly significant effect, pointing to an intensification of fragility in the second subperiod. ${ }^{5}$ We can therefore conclude that, when we control for the potential omission of variables through random country effects and time effects, institutions emerge as the only determinants of fragility, while other covariates such as income growth and investment lose their significance entirely.

\footnotetext{
${ }^{4}$ An alternative specification including political rights, in place of civil liberties, yields similar results even though the impact of political rights is estimated less precisely. Isham et al. (1997) also find that civil liberties are more closely associated than political rights to the ability of governments to exercise public decisions and authority.

${ }^{5}$ Similar results (which we omit for brevity) are obtained from probit specifications with added appropriate dummies.
} 
Table 2. The determinants of fragility

\begin{tabular}{|c|c|c|c|c|c|}
\hline & 1 & 2 & 3 & 4 & 5 \\
\hline Regressor & Probit $^{a, b}$ & Pooled OLS $S^{b}$ & $\begin{array}{c}\text { Random- } \\
\text { effects OLS }\end{array}$ & $\begin{array}{c}\text { Random- } \\
\text { effects OLS }\end{array}$ & $2 S L S^{c, d}$ \\
\hline Constant & & $\begin{array}{l}-2,3094 \\
(1,499)\end{array}$ & $\begin{array}{l}-1,7133 \\
(1,6675)\end{array}$ & $\begin{array}{l}-3,2887^{*} \\
(1,7102)\end{array}$ & $\begin{array}{l}-2,5826 \\
(1,6351)\end{array}$ \\
\hline pc GDP (log) & $\begin{array}{c}0,2321 \\
(0,4813) \\
\end{array}$ & $\begin{array}{c}0,1605 \\
(0,1006) \\
\end{array}$ & $\begin{array}{c}0,1484 \\
(0,1396) \\
\end{array}$ & $\begin{array}{c}0,1925 \\
(0,1341) \\
\end{array}$ & $\begin{array}{c}0,1737 \\
(0,1522) \\
\end{array}$ \\
\hline pc GDP growth & $\begin{array}{c}-0,0587 * * * \\
(0,0548) \\
\end{array}$ & $\begin{array}{c}-0,0289^{* *} \\
(0,011)\end{array}$ & $\begin{array}{l}-0,0153 \\
(0,0139) \\
\end{array}$ & $\begin{array}{l}-0,0228 \\
(0,0137) \\
\end{array}$ & $\begin{array}{l}-0,0097 \\
(0,0260)\end{array}$ \\
\hline Investment & $\begin{array}{l}0,0404^{*} \\
(0,0529)\end{array}$ & $\begin{array}{l}0,0215^{*} \\
(0,0113)\end{array}$ & $\begin{array}{c}0,0070 \\
(0,0124)\end{array}$ & $\begin{array}{c}0,0127 \\
(0,0121)\end{array}$ & $\begin{array}{c}0,0213 \\
(0,0213)\end{array}$ \\
\hline Primary enrollment & $\begin{array}{l}-0,0015 \\
(0,0079) \\
\end{array}$ & $\begin{array}{l}-0,0005 \\
(0,0018) \\
\end{array}$ & $\begin{array}{c}0,0013 \\
(0,0025) \\
\end{array}$ & $\begin{array}{c}-0,0002 \\
(0,0024)\end{array}$ & $\begin{array}{c}0,0005 \\
(0,0023)\end{array}$ \\
\hline $\begin{array}{l}\text { Government } \\
\text { expenditures }\end{array}$ & $\begin{array}{l}-0,0004 \\
(0,0181)\end{array}$ & $\begin{array}{c}0,0002 \\
(0,0041)\end{array}$ & $\begin{array}{c}0,0055 \\
(0,0047)\end{array}$ & $\begin{array}{c}0,0041 \\
(0,0046)\end{array}$ & $\begin{array}{c}0,0033 \\
(0,0062)\end{array}$ \\
\hline Trade & $\begin{array}{c}0,0006 \\
(0,0094)\end{array}$ & $\begin{array}{c}0,0008 \\
(0,0017)\end{array}$ & $\begin{array}{c}-9,3259 \mathrm{e}-05 \\
(0,0025)\end{array}$ & $\begin{array}{c}0,0004 \\
(0,0025)\end{array}$ & $\begin{array}{c}-3,9692 \mathrm{e}-05 \\
(0,0027)\end{array}$ \\
\hline Inflation & $\begin{array}{c}0,0002 \\
(0,0009)\end{array}$ & $\begin{array}{c}-3,5146 e-05 \\
(4,1752 \mathrm{e}-05)\end{array}$ & $\begin{array}{c}-3,1051 \mathrm{e}-05 \\
(9,4670 \mathrm{e}-05)\end{array}$ & $\begin{array}{c}-1,8955 e-05 \\
(9,2208 e-05)\end{array}$ & $\begin{array}{c}-6,9870 \mathrm{e}-05 \\
(4,7542 \mathrm{e}-05)\end{array}$ \\
\hline Life expectancy & $\begin{array}{c}0,0093 \\
(0,0422) \\
\end{array}$ & $\begin{array}{c}0,0027 \\
(0,0097) \\
\end{array}$ & $\begin{array}{c}0,0009 \\
(0,0101)\end{array}$ & $\begin{array}{c}0,0050 \\
(0,0098)\end{array}$ & $\begin{array}{c}0,0087 \\
(0,0126)\end{array}$ \\
\hline Fertility rate (log) & $\begin{array}{c}0,4812 \\
(1,6306)\end{array}$ & $\begin{array}{c}0,1118 \\
(0,3746)\end{array}$ & $\begin{array}{l}-0,2473 \\
(0,4403)\end{array}$ & $\begin{array}{c}0,3558 \\
(0,4795)\end{array}$ & $\begin{array}{l}-0,1707 \\
(0,4510)\end{array}$ \\
\hline $\begin{array}{l}\text { Ethnic } \\
\text { fractionalization }\end{array}$ & $\begin{array}{c}0,3197 \\
(1,2954) \\
\end{array}$ & $\begin{array}{c}0,2062 \\
(0,3320) \\
\end{array}$ & $\begin{array}{c}0,3231 \\
(0,3585) \\
\end{array}$ & $\begin{array}{c}0,1699 \\
(0,3417)\end{array}$ & $\begin{array}{c}0,5353 \\
(0,4322) \\
\end{array}$ \\
\hline Civil liberties & $\begin{array}{c}0,4095^{* * *} \\
(0,3032) \\
\end{array}$ & $\begin{array}{c}0,1992 * * * \\
(0,0496)\end{array}$ & $\begin{array}{c}0,2083^{* * *} \\
(0,0527)\end{array}$ & $\begin{array}{c}0,2290 * * * \\
(0,0510)\end{array}$ & $\begin{array}{l}0,1723^{* *} \\
(0,0844)\end{array}$ \\
\hline Revolutions & $\begin{array}{c}0,8364 * * * \\
(0,7082)\end{array}$ & $\begin{array}{c}0,4071^{* * * *} \\
(0,1472)\end{array}$ & $\begin{array}{l}0,3162 * \\
(0,1601)\end{array}$ & $\begin{array}{l}0,3201^{* *} \\
(0,1539)\end{array}$ & $\begin{array}{c}0,8985 * * \\
(0,4035)\end{array}$ \\
\hline Period dummy & & & & $\begin{array}{c}0,2041^{* *} \\
(0,0815)\end{array}$ & \\
\hline Mc Fadden $\mathrm{R}^{2}$ & 0,46 & & & & \\
\hline Adjusted $\mathrm{R}^{2}$ & 0,21 & 0,36 & 0,25 & 0,30 & 0,29 \\
\hline Observations & 75 & 75 & 75 & 75 & 75 \\
\hline
\end{tabular}

Notes: Panet dataset. ${ }^{a}$ Marginal effects. ${ }^{b}$ Robust standard errors in parentheses. ${ }^{c}$ Standard errors in parentheses. ${ }^{\mathrm{d}}$ The instruments are the values of all regressors at the beginning of each subperiod, i.e., in 1992 and 2000, respectively. ${ }^{*}$ significant at 10\%, ${ }^{* *}$ significant at 5\%, ${ }^{* * *}$ significant at $1 \%$.

The results presented so far need to be taken with caution, since our investigation is plagued by two major concerns: that for omitted variables, which we preliminarly address above with country and time effects, and that for endogeneity, which remains even if our dependend variable is constructed as the value of fragility in the final year of each cross section. To some extent, the two problems are actually linked, since the relationship between fragility and the selected regressors may be driven, 
rather than by direct causality, by an exogenous third factor which we have failed to include. However, in the discussion below we address each question separately.

\subsection{Extended specifications}

We reexamine the omitted variables issue by focusing, first of all, on the role of history, and in particular colonial history, which we have so far ignored. The potential impact of the colonial heritage within the literature on development and institutions has followed two parallel strands. One stresses the identity of the colonizers, while another points at the environmental conditions in the colonies. We exploit both strands, by experimenting with a set of colonial variables which reflect the two approaches. In particular, following Bertocchi and Canova (2002) we consider a set of three dummies capturing the national identity of the colonizers (namely, Britain, France, or Portugal), as well as a dummy for political status which distinguished among colonies, dependencies and independent countries (where the dummy takes value 2, 1, or 0, respectively). Moreover, following Acemoglu et al. (2001), we evaluate the potential role of settler mortality (in log) as a proxy of environmental conditions. We add each of these additional covariates, one by one, to the basic probit regression of Table 2, column 1. Results from the extended specifications are presented in Table 3. We find that the dummies for British (column 1) and French (column 2) colonies are significant and with opposite signs, which suggests that having being a British colony decreases the probability of being a fragile country, while the opposite occurs for French colonies. The relatively beneficial impact of British colonial domination confirms findings of several other studies, including Bertocchi and Canova (2002). However, the recognition of these factors does not alter the basic message regarding the impact of growth and institutions. The Portuguese colony dummy (column 3), as well as the dummy for political status (column 4), do not add any explicatory value to the basic regression. Including the latter, ethnic fractionalization emerges as one of the 
determinants of fragility, but the robustness of this link is clearly questionable. Settler mortality (column 5) is also insignificant.

Table 3. The determinants of fragility: colonial history

\begin{tabular}{|c|c|c|c|c|c|}
\hline Regressor & 1 & 2 & 3 & 4 & 5 \\
\hline pc GDP (log) & $\begin{array}{c}0,1760 \\
(0,5506)\end{array}$ & $\begin{array}{c}0,0928 \\
(0,5446)\end{array}$ & $\begin{array}{c}0,2147 \\
(0,4874)\end{array}$ & $\begin{array}{c}0,1319 \\
(0,6278)\end{array}$ & $\begin{array}{c}0,3203 \\
(0,9392)\end{array}$ \\
\hline pc GDP growth & $\begin{array}{c}-0,0622 * * * \\
(0,0593) \\
\end{array}$ & $\begin{array}{c}-0,0512^{* *} \\
(0,0585)\end{array}$ & $\begin{array}{c}-0,0619 * * * \\
(0,0551)\end{array}$ & $\begin{array}{c}-0,0708^{* *} \\
(0,0908)\end{array}$ & $\begin{array}{c}-0,1114^{* *} \\
(0,1521)\end{array}$ \\
\hline Investment & $\begin{array}{l}0,0497 * * \\
(0,0563)\end{array}$ & $\begin{array}{l}0,0399 * \\
(0,0553)\end{array}$ & $\begin{array}{c}0,0430 * * * \\
(0,0542)\end{array}$ & $\begin{array}{c}0,0493 * * \\
(0,0593)\end{array}$ & $\begin{array}{c}0,1264^{* *} \\
(0,1570)\end{array}$ \\
\hline Primary enrollment & $\begin{array}{c}0,0008 \\
(0,0087) \\
\end{array}$ & $\begin{array}{c}8,5136 \mathrm{e}-05 \\
(0,0083) \\
\end{array}$ & $\begin{array}{l}-0,0010 \\
(0,0082) \\
\end{array}$ & $\begin{array}{c}-0,0016 \\
(0,0104)\end{array}$ & $\begin{array}{c}0,0014 \\
(0,0149) \\
\end{array}$ \\
\hline $\begin{array}{l}\text { Government } \\
\text { expenditures }\end{array}$ & $\begin{array}{l}-0,0018 \\
(0,0191)\end{array}$ & $\begin{array}{c}0,0006 \\
(0,0198)\end{array}$ & $\begin{array}{l}-0,0030 \\
(0,0188)\end{array}$ & $\begin{array}{l}-0,0054 \\
(0,0296) \\
\end{array}$ & $\begin{array}{l}-0,0033 \\
(0,0509)\end{array}$ \\
\hline Trade & $\begin{array}{c}0,0010 \\
(0,0094)\end{array}$ & $\begin{array}{c}0,0024 \\
(0,0094)\end{array}$ & $\begin{array}{c}0,0003 \\
(0,0092)\end{array}$ & $\begin{array}{c}0,0016 \\
(0,0121)\end{array}$ & $\begin{array}{l}-0,0078 \\
(0,019)\end{array}$ \\
\hline Inflation & $\begin{array}{c}0,0004 \\
(0,0009) \\
\end{array}$ & $\begin{array}{c}0,0004 \\
(0,0009) \\
\end{array}$ & $\begin{array}{c}9,3748 \mathrm{e}-05 \\
(0,0009) \\
\end{array}$ & $\begin{array}{c}0,0003 \\
(0,0010)\end{array}$ & $\begin{array}{l}-0,0002 \\
(0,0005)\end{array}$ \\
\hline Life expectancy & $\begin{array}{c}0,0065 \\
(0,0413)\end{array}$ & $\begin{array}{l}-0,0031 \\
(0,0455)\end{array}$ & $\begin{array}{c}0,0152 \\
(0,0449)\end{array}$ & $\begin{array}{c}0,0019 \\
(0,0486)\end{array}$ & $\begin{array}{l}-0,0015 \\
(0,0720)\end{array}$ \\
\hline Fertility rate (log) & $\begin{array}{c}0,1884 \\
(1,5819) \\
\end{array}$ & $\begin{array}{c}0,3020 \\
(1,4821)\end{array}$ & $\begin{array}{c}0,4286 \\
(1,7086)\end{array}$ & $\begin{array}{c}0,7670 \\
(2,0978)\end{array}$ & $\begin{array}{c}0,0073 \\
(3,5484) \\
\end{array}$ \\
\hline $\begin{array}{l}\text { Ethnic } \\
\text { fractionalization }\end{array}$ & $\begin{array}{c}0,5952 \\
(1,3720)\end{array}$ & $\begin{array}{c}0,3415 \\
(1,3411)\end{array}$ & $\begin{array}{c}0,2900 \\
(1,2990)\end{array}$ & $\begin{array}{l}1,2095 * * \\
(1,5223)\end{array}$ & $\begin{array}{c}1,1557 \\
(2,0727)\end{array}$ \\
\hline Civil liberties & $\begin{array}{c}0,3659 * * * \\
(0,2584) \\
\end{array}$ & $\begin{array}{c}0,4009 * * * \\
(0,2848)\end{array}$ & $\begin{array}{c}0,4600 * * * \\
(0,3209) \\
\end{array}$ & $\begin{array}{c}0,3968 * * * \\
(0,3248) \\
\end{array}$ & $\begin{array}{c}0,3676 * * * \\
(0,3607) \\
\end{array}$ \\
\hline Revolutions & $\begin{array}{c}0,9473 * * * \\
(0,7848)\end{array}$ & $\begin{array}{c}0,832854 * * * \\
(0,6962)\end{array}$ & $\begin{array}{c}0,9058 * * * \\
(0,7224)\end{array}$ & $\begin{array}{c}0,764054 * * * \\
(0,7738)\end{array}$ & $\begin{array}{l}0,9456^{*} \\
(1,3353)\end{array}$ \\
\hline British colony & $\begin{array}{c}-0,3736^{* *} \\
(0,5096)\end{array}$ & & & & \\
\hline French colony & & $\begin{array}{l}0,3476 * \\
(0,5344) \\
\end{array}$ & & & \\
\hline Portuguese colony & & & $\begin{array}{c}0,4266 \\
(0,8675)\end{array}$ & & \\
\hline Political status & & & & $\begin{array}{l}-0,0591 \\
(0,3555) \\
\end{array}$ & \\
\hline Settler mortality & & & & & $\begin{array}{c}0,2418 \\
(0,5944)\end{array}$ \\
\hline Mc Fadden $\mathrm{R}^{2}$ & 0,50 & 0,49 & 0,48 & 0,52 & 0,53 \\
\hline Adjusted $\mathrm{R}^{2}$ & 0,23 & 0,22 & 0,21 & 0,22 & 0,11 \\
\hline Observations & 75 & 75 & 75 & 67 & 48 \\
\hline
\end{tabular}

Notes: Panet dataset. Probit marginal effects. Robust standard errors in parentheses. ${ }^{*}$ significant at $10 \%$,** significant at $5 \%$, *** significant at $1 \%$. 
While in Table 3 we present a pooled specification, to increase the chances for the added variables to exert a significant impact, in unreported regressions we repeat the exercise running panel OLS with random country effects, with and without the period dummy, to find that the only significant colonial variable is British colony, while once again civil liberties and revolutions are confirmed, unlike growth and investment. ${ }^{6}$ Similar results obtain when, in order to maximize the estimated sample size, the colonial variables are added to a more parsimonious specification including only those variables which are significant in the basic specification, i.e., the growth rate, investment, civil liberties and revolutions. Therefore, we can conclude that the additional explanatory power coming from the recognition of colonial history is limited and does not alter previous conclusions, possibly because the impact of these factors is already largely accounted for by the standard regressors, or else because their variability within SSA is limited. In a similar vein, Bhattacharyya (2009) also casts doubts on the ability of colonial legacy to explain African underdevelopment.

Along the same lines of Table 3, in Table 4 we add a number of additional covariates reflecting other possible channels of influence. In column 1 and 2 we add one by one two geographical variables, namely a country’s latitude and a dummy reflecting the fact that a country is landlocked. They are both insignificant, and leave previous conclusions unaltered. ${ }^{7}$ In columns 3, 4 and 5, we add one by one three of the Kaufmann et al. (2009) indexes, namely government effectiveness, rule of law, and voice and accountability. To be noticed is that these variables are highly correlated with fragility $(-0.71,-0.61,-0.58$, respectively), but at the same time they are also highly correlated with our institutional variables: their correlation coefficients with civil liberties are $-0.63,-0.70$, and 0.92, respectively, while with revolutions they are $-0.54,-0.52$, and -0.43 . Unsurprisingly, in

\footnotetext{
${ }^{6}$ To be noticed that country fixed effects are precluded by the time invariant nature of the colonial variables.

${ }^{7}$ When each of these variables is added to a more parsimonious specification including only those variables which are significant in the basic specification, i.e., the growth rate, investment, civil liberties and revolutions, they both show a significantly positive impact. This suggests that there may be a link between geography and fragility that runs through a wide array of channels.
} 
column 3 government effectiveness appears highly significant but displaces the significance of revolutions, while rule of law in column 4 interferes both with revolutions and civil liberties, and voice and accountability replaces the role of civil liberties in column 5.

Table 4. The determinants of fragility: additional covariates

\begin{tabular}{|c|c|c|c|c|c|}
\hline Regressor & 1 & 2 & 3 & 4 & 5 \\
\hline pc GDP (log) & $\begin{array}{c}0,2820 \\
(0,4897)\end{array}$ & $\begin{array}{c}0,2648 \\
(0,5266)\end{array}$ & $\begin{array}{c}0,2261 \\
(0,7701)\end{array}$ & $\begin{array}{c}0,0111 \\
(0,6367)\end{array}$ & $\begin{array}{c}0,2933 \\
(0,5371)\end{array}$ \\
\hline pc GDP growth & $\begin{array}{c}-0,0739 * * * \\
(0,0659) \\
\end{array}$ & $\begin{array}{c}-0,0709 * * * \\
(0,0604) \\
\end{array}$ & $\begin{array}{c}-0,0716^{* *} \\
(0,0939)\end{array}$ & $\begin{array}{l}-0,0415^{*} \\
(0,0616) \\
\end{array}$ & $\begin{array}{c}-0,0460^{* *} \\
(0,0574)\end{array}$ \\
\hline Investment & $\begin{array}{c}0,0555 * * * \\
(0,0525)\end{array}$ & $\begin{array}{l}0,0635 * * \\
(0,0694)\end{array}$ & $\begin{array}{c}0,0797 * * * \\
(0,0623)\end{array}$ & $\begin{array}{c}0,0377 \\
(0,0646)\end{array}$ & $\begin{array}{l}0,0466^{* *} \\
(0,0557)\end{array}$ \\
\hline Primary enrollment & $\begin{array}{c}0,0010 \\
(0,0086)\end{array}$ & $\begin{array}{l}-0,0025 \\
(0,0084)\end{array}$ & $\begin{array}{c}0,0009 \\
(0,0114)\end{array}$ & $\begin{array}{l}-0,0077^{*} \\
(0,0107)\end{array}$ & $\begin{array}{l}-0,0026 \\
(0,0084)\end{array}$ \\
\hline $\begin{array}{l}\text { Government } \\
\text { expenditures }\end{array}$ & $\begin{array}{c}0,0015 \\
(0,0171)\end{array}$ & $\begin{array}{c}0,0016 \\
(0,0195)\end{array}$ & $\begin{array}{c}0,0021 \\
(0,0295)\end{array}$ & $\begin{array}{c}0,0008 \\
(0,0241)\end{array}$ & $\begin{array}{c}0,0006 \\
(0,0197)\end{array}$ \\
\hline Trade & $\begin{array}{l}-0,0008 \\
(0,0085)\end{array}$ & $\begin{array}{l}-0,0022 \\
(0,0114)\end{array}$ & $\begin{array}{c}0,0077 \\
(0,0144)\end{array}$ & $\begin{array}{c}0,0055 \\
(0,0137)\end{array}$ & $\begin{array}{l}-0,0029 \\
(0,0112)\end{array}$ \\
\hline Inflation & $\begin{array}{c}8,0161 \mathrm{e}-05 \\
(0,0009)\end{array}$ & $\begin{array}{c}8,3770 \mathrm{e}-05 \\
(0,0009)\end{array}$ & $\begin{array}{l}-0,0001 \\
(0,0013)\end{array}$ & $\begin{array}{c}9,1683 e-05 \\
(0,0009)\end{array}$ & $\begin{array}{c}-3,4901 \mathrm{e}-05 \\
(0,0009)\end{array}$ \\
\hline Life expectancy & $\begin{array}{c}-0,0051 \\
(0,05338)\end{array}$ & $\begin{array}{l}-0,0024 \\
(0,0433)\end{array}$ & $\begin{array}{l}0,0347^{* *} \\
(0,0430)\end{array}$ & $\begin{array}{c}0,0171 \\
(0,0405)\end{array}$ & $\begin{array}{c}0,0123 \\
(0,0434)\end{array}$ \\
\hline Fertility rate (log) & $\begin{array}{c}0,0762 \\
(1,7224)\end{array}$ & $\begin{array}{c}0,4291 \\
(1,7129)\end{array}$ & $\begin{array}{c}0,3974 \\
(1,9877)\end{array}$ & $\begin{array}{l}-0,3799 \\
(1,7697)\end{array}$ & $\begin{array}{c}0,1339 \\
(1,8559)\end{array}$ \\
\hline $\begin{array}{l}\text { Ethnic } \\
\text { fractionalization }\end{array}$ & $\begin{array}{c}0,1667 \\
(1,4217)\end{array}$ & $\begin{array}{c}0,3829 \\
(1,3192)\end{array}$ & $\begin{array}{c}0,5991 \\
(1,8575)\end{array}$ & $\begin{array}{c}0,2470 \\
(1,4157)\end{array}$ & $\begin{array}{c}0,3436 \\
(1,1990)\end{array}$ \\
\hline Civil liberties & $\begin{array}{l}0,3636 * * * \\
(0,25056)\end{array}$ & $\begin{array}{c}0,3930 * * * \\
(0,3041)\end{array}$ & $\begin{array}{c}0,4285^{* * * *} \\
(0,3877)\end{array}$ & $\begin{array}{l}0,2114^{*} \\
(0,3240)\end{array}$ & $\begin{array}{l}-0,0013 \\
(0,4666)\end{array}$ \\
\hline Revolutions & $\begin{array}{c}0,8256 * * * \\
(0,6834)\end{array}$ & $\begin{array}{c}0,8653 * * * \\
(0,7423)\end{array}$ & $\begin{array}{c}0,3501 \\
(0,8447)\end{array}$ & $\begin{array}{c}0,4167 \\
(0,8237)\end{array}$ & $\begin{array}{c}0,7480 * * * \\
(0,7123)\end{array}$ \\
\hline Latitude & $\begin{array}{c}0,0155 \\
(0,0269)\end{array}$ & & & & \\
\hline Landlock & & $\begin{array}{l}-0,3321 \\
(0,5835)\end{array}$ & & & \\
\hline $\begin{array}{l}\text { Government } \\
\text { effectiveness }\end{array}$ & & & $\begin{array}{c}-2,2111^{* * *} \\
(1,8500)\end{array}$ & & \\
\hline Rule of law & & & & $\begin{array}{c}-1,0282 * * * \\
(0,7134) \\
\end{array}$ & \\
\hline $\begin{array}{l}\text { Voice and } \\
\text { accountability }\end{array}$ & & & & & $\begin{array}{c}-0,9273 * * * \\
(0,8921)\end{array}$ \\
\hline Mc Fadden $\mathrm{R}^{2}$ & 0,48 & 0,48 & 0,75 & 0,58 & 0,53 \\
\hline Adjusted $\mathrm{R}^{2}$ & 0,21 & 0,21 & 0,48 & 0,31 & 0,26 \\
\hline Observations & 75 & 75 & 75 & 75 & 75 \\
\hline
\end{tabular}

Notes: Panet dataset. Probit marginal effects. Robust standard errors in parentheses. * significant at $10 \%,{ }^{* *}$ significant at $5 \%, * * *$ significant at $1 \%$. 
Similar conclusions can be achieved in specifications including different combinations of the variables under consideration. This suggests that the set of variables under consideration captures the same phenomena, and that the relevance of institutions is robust to their alternative measures.

\subsection{Controlling for endogeneity}

While institutional variables emerge from the previous analysis as candidate explanations of fragility, it is conceivable that fragility, rather than being caused by bad institutions, may well be the cause behind them. The potential problem is mitigated by the fact that our dependend variable is constructed as the value of fragility in the final year of each cross section, so that the lagging of the regressors allows for some control of reverse causality, which however cannot be ruled out under serial correlation in fragility. To address the issue, we first turn once again to colonial history as a source of possible instruments. However, this avenue is impeded by the fact that our colonial variables prove to be very weak instruments for all the variables we select as potentially significant, i.e., revolutions, civil liberties and GDP growth, as revealed by the first stages of 2SLS regressions we run. In particular, the fact that in our context settler mortality is an irrelevant instrument is probably to be attributed to the limited SSA sample we focus on. This evidence leads us to the conclusion that, within Africa, a strategy similar to that pursued by Acemoglu et al. (2001) cannot be applied, possibly because of insufficient cross country variation along the environmental dimension.

An alternative solution for the endogeneity problem is to employ as instruments the lagged values of all regressors. The rationale is simply that this procedures at least ensures that the values of the regressors are determined prior to those of the dependent variable. Since our dataset only includes two subperiods, to avoid losing half of the observations we prefer to employ as instruments the values of all regressors at the beginning of each subperiod, i.e., in 1992 and 2000, respectively. We 
present the second stage of the estimates in Table 2, column 5, where we show that civil liberties and revolutions are the only residual significant variables, even if the precision of their estimated coefficient is partially reduced. ${ }^{8}$

To conclude, by addressing endogeneity we can conclude that, first, colonial history is not offering useful instruments and that, second, institutions, but not GDP growth or investment, are confirmed as exogenous determinants of fragility.

\subsection{A post-war perspective}

In the effort to find the long run roots of fragility, in this subsection we explore a further avenue, by focussing on the potential impact of the entire post-war period performance. Given the limited range of years over which information on fragility is available, so far we have been able to consider only a relatively short time period running from 1992 to 2007. To fully exploit the available information on our selected regressors, we assemble a new cross sectional dataset covering the same 41 countries from the year 1960. The dependent variable is constructed as the average of the fragility dummy in the 1999-2007 period. The regressors are the averages of the previously considered variables over the 1960-1998 period. ${ }^{9}$ The resulting estimates therefore allow to evaluate the long run impact of the selected variables on the dependent variable. Implicitly, the new approach is less likely to suffer of the endogeneity problem, since the observations for the variables entered as regressors clearly predate those of the dependent variable.

Since the dependent variable is no longer a binary variable, we perform OLS regressions which we present in Table 5, for the same specification presented in Table 2, columns 1 and 2.

\footnotetext{
${ }^{8}$ Very similar results are obtained when only GDP growth, civil liberties and revolutions are instrumented with their initial values.

${ }^{9}$ Redefinitions of the time spans under consideration do not alter our results.
} 
Table 5. The determinants of fragility: a post-war perspective

\begin{tabular}{|c|c|c|c|c|c|}
\hline Regressor & 1 & 2 & 3 & 4 & 5 \\
\hline constant & $\begin{array}{l}4,8961 * \\
(2,5136)\end{array}$ & $\begin{array}{l}4,8672 * \\
(2,6137)\end{array}$ & $\begin{array}{l}5,0595 * \\
(2,5678)\end{array}$ & $\begin{array}{l}5,3036 * \\
(2,6566)\end{array}$ & $\begin{array}{l}6,7350 * \\
(3,5121)\end{array}$ \\
\hline pc GDP (log) & $\begin{array}{c}0,4616^{* *} \\
(0,1842)\end{array}$ & $\begin{array}{c}0,4659 * * \\
(0,1970)\end{array}$ & $\begin{array}{c}0,4357 * * \\
(0,2079)\end{array}$ & $\begin{array}{c}0,5230 * * * \\
(0,1753)\end{array}$ & $\begin{array}{c}0,4660 * * \\
(0,2168)\end{array}$ \\
\hline pc GDP growth & $\begin{array}{l}-0,0561 \\
(0,0554) \\
\end{array}$ & $\begin{array}{l}-0,0560 \\
(0,0568) \\
\end{array}$ & $\begin{array}{l}-0,0496 \\
(0,0524) \\
\end{array}$ & $\begin{array}{c}-0,0452 \\
(0,0523)\end{array}$ & $\begin{array}{l}-0,0813 \\
(0,0768) \\
\end{array}$ \\
\hline Investment & $\begin{array}{l}0,0293^{*} \\
(0,0152)\end{array}$ & $\begin{array}{l}0,0294^{*} \\
(0,0157)\end{array}$ & $\begin{array}{l}0,0289 * \\
(0,0164)\end{array}$ & $\begin{array}{l}0,0375^{*} \\
(0,0184)\end{array}$ & $\begin{array}{l}0,0407^{*} \\
(0,0228) \\
\end{array}$ \\
\hline Primary enrollment & $\begin{array}{l}-0,0002 \\
(0,0035)\end{array}$ & $\begin{array}{l}-0,0003 \\
(0,0038)\end{array}$ & $\begin{array}{c}0,0004 \\
(0,0039)\end{array}$ & $\begin{array}{c}3,1109 \mathrm{e}-06 \\
(0,0036)\end{array}$ & $\begin{array}{c}0,0006 \\
(0,0048)\end{array}$ \\
\hline $\begin{array}{l}\text { Government } \\
\text { expenditures }\end{array}$ & $\begin{array}{c}0,0046 \\
(0,0091)\end{array}$ & $\begin{array}{c}0,0048 \\
(0,0091)\end{array}$ & $\begin{array}{c}0,0037 \\
(0,0098)\end{array}$ & $\begin{array}{c}0,0112 \\
(0,0105)\end{array}$ & $\begin{array}{c}0,0042 \\
(0,0097)\end{array}$ \\
\hline Trade & $\begin{array}{l}-0,0016 \\
(0,0039)\end{array}$ & $\begin{array}{l}-0,0017 \\
(0,0040)\end{array}$ & $\begin{array}{l}-0,0017 \\
(0,0041)\end{array}$ & $\begin{array}{l}-0,0048 \\
(0,0041)\end{array}$ & $\begin{array}{c}-0,0071 \\
(0,0066)\end{array}$ \\
\hline Inflation & $\begin{array}{c}-6,3865 e-05 \\
(0,0002)\end{array}$ & $\begin{array}{c}-6,1980 \mathrm{e}-05 \\
(0,0002)\end{array}$ & $\begin{array}{c}-3,0704 \mathrm{e}-05 \\
(0,0002)\end{array}$ & $\begin{array}{c}-3,6494 \mathrm{e}-06 \\
(0,0002)\end{array}$ & $\begin{array}{c}-4,5257 \mathrm{e}-05 \\
(0,0003)\end{array}$ \\
\hline Life expectancy & $\begin{array}{l}-0,0333 \\
(0,0204)\end{array}$ & $\begin{array}{l}-0,0334 \\
(0,0210)\end{array}$ & $\begin{array}{c}-0,0341 \\
(0,0207)\end{array}$ & $\begin{array}{l}-0,0406^{*} \\
(0,0199)\end{array}$ & $\begin{array}{l}-0,0281 \\
(0,0232)\end{array}$ \\
\hline Fertility rate (log) & $\begin{array}{l}-1,0497 \\
(1,0097) \\
\end{array}$ & $\begin{array}{l}-1,0473 \\
(1,0390) \\
\end{array}$ & $\begin{array}{c}-0,9908 \\
(1,0290) \\
\end{array}$ & $\begin{array}{l}-1,2386 \\
(0,9992) \\
\end{array}$ & $\begin{array}{l}-1,2429 \\
(0,9556) \\
\end{array}$ \\
\hline $\begin{array}{l}\text { Ethnic } \\
\text { fractionalization }\end{array}$ & $\begin{array}{c}0,0879 \\
(0,3702)\end{array}$ & $\begin{array}{c}0,0877 \\
(0,3811)\end{array}$ & $\begin{array}{c}0,0603 \\
(0,3689)\end{array}$ & $\begin{array}{c}0,1977 \\
(0,3990)\end{array}$ & $\begin{array}{c}0,2954 \\
(0,4733)\end{array}$ \\
\hline Civil liberties & $\begin{array}{c}-1,9112 * * \\
(0,7217)\end{array}$ & $\begin{array}{c}-1,9155^{* *} \\
(0,7366)\end{array}$ & $\begin{array}{c}-1,9469 * * \\
(0,7606)\end{array}$ & $\begin{array}{c}-1,9697 * * \\
(0,7926) \\
\end{array}$ & $\begin{array}{c}-2,6228 * * \\
(0,9999) \\
\end{array}$ \\
\hline Civil liberties $^{2}$ & $\begin{array}{c}0,1960 * * \\
(0,0753)\end{array}$ & $\begin{array}{c}0,1966 * * \\
(0,0768)\end{array}$ & $\begin{array}{c}0,1987 * * \\
(0,0788)\end{array}$ & $\begin{array}{c}0,1994 * * \\
(0,0826)\end{array}$ & $\begin{array}{c}0,2725^{* *} \\
(0,1023)\end{array}$ \\
\hline Revolutions & $\begin{array}{c}0,5168 \\
(0,3962)\end{array}$ & $\begin{array}{c}0,5132 \\
(0,4126)\end{array}$ & $\begin{array}{c}0,5766 \\
(0,4244)\end{array}$ & $\begin{array}{c}0,4460 \\
(0,4139)\end{array}$ & $\begin{array}{c}0,0747 \\
(0,4947)\end{array}$ \\
\hline British colony & & $\begin{array}{c}0,0136 \\
(0,1417) \\
\end{array}$ & & & \\
\hline French colony & & & $\begin{array}{c}0,0869 \\
(0,1722)\end{array}$ & & \\
\hline Portuguese colony & & & & $\begin{array}{l}-0,3879 \\
(0,3326) \\
\end{array}$ & \\
\hline Political status & & & & & $\begin{array}{l}-0,0254 \\
(0,1927)\end{array}$ \\
\hline Adjusted $\mathrm{R}^{2}$ & 0,27 & 0,23 & 0,24 & 0,29 & 0,18 \\
\hline Observations & 37 & 37 & 37 & 37 & 33 \\
\hline
\end{tabular}

Notes: Cross-sectional dataset. OLS coefficients. Robust standard errors in parentheses. * significant at $10 \%,{ }^{* *}$ significant at $5 \%$, ${ }^{* * *}$ significant at $1 \%$.

We find evidence of a positive impact on fragility of income and investment. This confirms that fragility is not necessarily associated with worse economic performances. As for the reasons of this outcome, we can again conjecture that relatively favourable economic conditions can trigger 
corruption and predation activities ultimately leading to fragility. Turning to institutions, we find that, over this longer time span, the impact of revolutions vanishes, possibly because revolutions represent a relatively short run, albeit acute symptom of bad institutions, or else because in some instances revolutions may clear the way to a more stable order. The impact of civil liberties is confirmed, which is not surprising given its relatively inertial dynamics. However, taking into account the entire post-colonial era, it becomes more complex, since it displays a convex behavior, which suggests that a higher degree of fragility is associated with extreme values of the index. In other words, fragility is more likely both under extreme autocracies and under very liberal democracies. A consequence of this finding it that a gradual improvement can be detrimental for growth. The reason why even under the latter type of regime fragility is facilitated is that populistic governments may be unable to adopt beneficial but unpopular economic policies, with a consequent increase in the risk of political disorder. In the subsequent columns, we add one by one our colonial variables, which are never significant. The regression including settler mortality is omitted from the table since due to the small estimated sample size (24) none of the regressors reaches an acceptable level of precision. Additional unreported regressions confirm the irrelevancy of geographical variables.

\subsection{Summary}

We can conclude our empirical investigations by pointing at institutions as the predominant cause of fragility. Purely economic factors such as the level of income, its growth rate, or investment, have a non robust impact on the dependent variable, and in some cases even run in the direction of making fragility more likely under better economic performances. Colonial history, which we introduce by accounting both for the identity of the colonizers and for the environmental conditions in the colonies, appears to be only marginally relevant for fragility, once we control for contemporary institutions. 
Our results can be compared with those obtained by Carment et al. (2008) over a cross sectional world sample of 156 countries covering the 1999-2005 period, despite the fact that they employ the CFIP rather that the CPIA indicator for fragility. The main difference emerging from the their investigation is that, over their world sample, a lower per capita income level appears to be associated with higher fragility, while all other potential determinants lose significance once reverse causality is controlled for. This radically different conclusion can be explained by the specificity of the African region, as suggested also by the positive coefficient of a dummy for Africa when the world sample is employed. We can also compare our results with Fosu (2008), who focuses like us on a SSA sample, but considers a different albeit related criterion to define his dependent variable, since he investigates the determinants of anti-growth policy syndromes. Among these syndromes, he includes the fragility-related concept of state breakdown, which is defined as a condition involving civil wars and acute political instability (Fosu and O’Connell, 2006). However, state breakdown is only one component, since policy syndromes are defined as combination of this symptom with state controls, adverse redistribution, and suboptimal inter-temporal resource allocation. Nonetheless, he finds that syndrome-free regimes are facilitated by a number of factors, among which the initial geo-political conditions, resource availability and political institutions.

\section{Conclusion}

With a focus on SSA, we have explored the determinants of fragility by considering a wide array of potential factors. Besides economic, demographic, and institutional determinants, we have also considered the unique role of the history and geopraphy of the area. Our findings suggest that contemporary institutions are the central drivers of fragility. 
Even if we find a limited role for colonial history, we cannot exclude that the institutional variables themselves may still be affected by long term factors that can even predate colonial dominations, as suggested by Herbst (2000), who focuses on the underdevelopment of precolonial polities as an explanation of the weakness of postcolonial states. Along the same lines, Bockstette et al. (2002) observe that state antiquity, a measure of the depth of experience with state level institutions, is positively correlated with institutional quality, while Gennaioli and Rainer (2007) uncover for Africa a positive association between stronger precolonial political institutions and public goods provision. Finally, Nunn (2008) finds that weakened and fragmented states may be the result of the slave trades. Further empirical research is needed on the link between fragility and these factors.

While the literature we have surveyed is purely empirical, theoretical models of fragility have recently been proposed with a specific focus on the related fiscal concept of state capacity. Besley and Persson (2010) develop a model of state capacity which accounts for the risk of external or internal conflict, the degree of political instability, and dependence on natural resources. Acemoglu (2010) derives the political equilibrium of a model of state capacity. We can build on these contributions to develop a dynamic, political economy model of fragility, which can explain the empirical links we have highlighted. This is in our agenda for future research.

\section{REFERENCES}

Acemoglu, D., 2010. Institutions, Factor Prices and Taxation: Virtues of Strong States. American Economic Review Papers and Proceedings 100, forthcoming.

Acemoglu, D., Johnson, S., Robinson, J. A., 2001. The Colonial Origins of Comparative Development: An Empirical Investigation. American Economic Review 91, 1369-1401. 
Alesina, A., Devleeschauwer, A., Easterly, W., Kurlat, S., Wacziarg, R., 2003. Fractionalization. Journal of Economic Growth 8, 155-194.

Baliamoune-Lutz, M., 2009. Institutions, Trade, and Social Cohesion in Fragile States: Implications for Policy Conditionality and Aid Allocation. Journal of Policy Modeling 31, 877-890.

Barro, R. J., 1991. Economic Growth in a Cross Section of Countries. Quarterly Journal of Economics 106, 407-444.

Besley, T. J., Persson, T., 2010. State Capacity, Conflict and Development. Econometrica, forthcoming.

Bhattacharyya, S., 2009. Root Causes of African Underdevelopment. Journal of African Economies $18,745-780$.

Bertocchi, G., Canova, F., 2002. Did Colonization Matter for Growth? An Empirical Exploration into the Historical Causes of Africa's Underdevelopment. European Economic Review 46, 18511871.

Bertocchi, G., Guerzoni, A., 2010. The Fragile Definition of State Fragility. Mimeo. University of Modena.

Bockstette, V., Chanda, A., Putterman, L., 2002. States and Markets: The Advantage of an Early Start. Journal of Economic Growth 7, 347-369. 
Burnside, C., Dollar, D., 2000. Aid, Policies and Growth. American Economic Review 90, 847-868.

Carment, D., Prest, S., Samy, Y., 2008. Determinants of State Fragility and Implications for Aid Allocation: An Assessment Based on the Country Indicators for Foreign Policy Project. Conflict Management and Peace Science 25, 349-373.

Chauvet, L., Collier, P., 2007. What are the Preconditions for Turnarounds in Failing States? Journal of Peace and Conflict Management, forthcoming.

Carl-Johan Dalgaard, C., Hansen, H., Tarp, F., 2004. On The Empirics of Foreign Aid and Growth. Economic Journal 114, F191-F216.

Easterly, W., Levine, R., 1997. Africa’s Growth Tragedy: Policies and Ethnic Divisions. Quarterly Journal of Economics 112, 1203-1250.

Engerman, S. L., Sokoloff, K. L., 1997. Factor Endowments, Institutions, and Differential Paths of Growth Among New World Economies: A View from Economic Historians of the United States. In Harber, S. (Ed.). How Latin America Fell Behind. Stanford University Press. Stanford, CA. 260304.

European Report on Development (ERD), 2009. Overcoming Fragility in Africa. Robert Schuman Centre for Advanced Studies. European University Institute. San Domenico di Fiesole.

Fosu, A. K., 2009. Understanding the African Growth Record: The Importance of Policy Syndromes and Governance. UNU-WIDER Discussion Paper No. 2009/02. 
Fosu, A. K., 2008. Anti-Growth Syndromes in Africa: A Synthesis of the Case Studies. In Ndulu, B., O’Connell, S., Bates, R., Collier, P., Soludo, C. (Eds.). The Political Economy of Economic Growth in Africa 1960-2000. Cambridge University Press. Cambridge. 137-72.

Fosu, A. K., O’Connell, S., 2006. Explaining African Economic Growth: The Role of Anti-growth Syndromes. In Bourguignon, F., Pleskovic, B. (Eds.). Annual Bank Conference on Development Economics (ABCDE). World Bank. Washington, DC. 31-66.

Gennaioli, N., Rainer, I., 2007. The Modern Impact of Precolonial Centralization in Africa. Journal of Economic Growth 12, 185-234.

Hall, R. E., Jones, C. I., 1999. Why Do Some Countries Produce So Much More Output Per Worker Than Others? Quarterly Journal of Economics 114, 83-116.

Hansen, H., Tarp, F., 2001. Aid and Growth Regressions. Journal of Development Economics 64, $547-570$.

Herbst, J., 2000. States and Power in Africa: Comparative Lessons in Authority and Control. Princeton University Press. Princeton, NJ.

Isham, J., Kaufmann, D., Pritchett, L. H., 1997. Civil Liberties, Democracy, and the Performance of Government Projects. World Bank Economic Review 11, 219-42.

Kaufman, D., Kraay, A., Mastruzzi, M., 2009. Governance Matters VIII: Aggregate and Individual Governance Indicators, 1996-2008. World Bank Policy Research Working Paper No. 4978. 
Landes, D. S., 1998. The Wealth and Poverty of Nations: Why Some Are So Rich and Some So Poor. W. W. Norton \& Co.. New York, NY.

La Porta, R., Lopez-de-Silanes, F., Shleifer, A., Vishny, R. W., 1998. Law and Finance. Journal of Political Economy 106, 1113-1155.

McGillivray, M., Feeny, S., 2008. Aid and Growth in Fragile States. UNU-WIDER Research Paper No. 2008/3.

North, D. C., Summerhill, W., Weingast, B., 2000. Order, Disorder and Economic Change: Latin America vs. North America. In Bueno de Mesquita, B., Root, H. (Eds.). Governing for Prosperity. Yale University Press. New Haven, CT. 17-58.

Nunn, N., 2008. The Long-Term Effects of Africa’s Slave Trades. Quarterly Journal of Economics 123, 139-176.

Sachs, J. D., Warner, A. M., 1997. Sources of Slow Growth in African Economies. Journal of African Economies 6, 335-376.

Vallings, C., Moreno-Torres, M., 2005. Drivers of Fragility: What Makes States Fragile? PRDE Working Paper No. 7. 


\section{DATA APPENDIX}

\begin{tabular}{|c|c|c|}
\hline Variable & Description & Source \\
\hline Fragility & $\begin{array}{l}\text { Binary variable assuming value } 1 \text { for } \\
\text { IDA countries in the bottom two } \\
\text { CPIA quintiles or without a CPIA } \\
\text { rating, } 0 \text { otherwise }\end{array}$ & $\begin{array}{l}\text { World Bank and Baliamoune-Lutz } \\
\text { (2009) }\end{array}$ \\
\hline pc GDP & Real per capita GDP & Penn World Table 6.2 \\
\hline pc GDP growth & $\begin{array}{l}\text { Annual growth rate of real per capita } \\
\text { GDP }\end{array}$ & Penn World Table 6.2 \\
\hline Investment & Investment over real GDP & Penn World Table 6.2 \\
\hline $\begin{array}{l}\text { Primary } \\
\text { enrollment }\end{array}$ & $\begin{array}{l}\text { Primary enrollment over official } \\
\text { school age population }\end{array}$ & $\begin{array}{l}\text { World Bank Education Statistics } \\
5.3\end{array}$ \\
\hline $\begin{array}{l}\text { Government } \\
\text { expenditures }\end{array}$ & $\begin{array}{l}\text { Government expenditures over real } \\
\text { GDP }\end{array}$ & Penn World Table 6.2 \\
\hline Trade & $\begin{array}{l}\text { Sum of import and export over real } \\
\text { GDP }\end{array}$ & Penn World Table 6.2 \\
\hline Inflation & Consumer price index & International Monetary Fund \\
\hline Life expectancy & $\begin{array}{l}\text { Number of years of life expectancy } \\
\text { at birth }\end{array}$ & Cross-National Time Series (2001) \\
\hline Fertility rate & Number of children per woman & $\begin{array}{l}\text { World Bank World Development } \\
\text { Indicators (2008) }\end{array}$ \\
\hline $\begin{array}{l}\text { Ethnic } \\
\text { fractionalization }\end{array}$ & Ethnic fractionalization index & Alesina et al. (2003) \\
\hline Civil liberties & Civil liberties index & Freedom House (2008) \\
\hline Revolutions & Number of revolutions & Cross-National Time Series (2001) \\
\hline British colony & $\begin{array}{l}\text { Binary variable assuming value } 1 \text { for } \\
\text { former British colonies, } 0 \text { otherwise }\end{array}$ & African Research Program \\
\hline French colony & $\begin{array}{l}\text { Binary variable assuming value } 1 \text { for } \\
\text { former French colonies, } 0 \text { otherwise }\end{array}$ & African Research Program \\
\hline $\begin{array}{l}\text { Portuguese } \\
\text { colony }\end{array}$ & $\begin{array}{l}\text { Binary variable assuming value } 1 \text { for } \\
\text { former Portuguese colonies, } 0 \\
\text { otherwise }\end{array}$ & African Research Program \\
\hline Political status & $\begin{array}{l}\text { Categorical variable assuming value } \\
2 \text { for colonies, } 1 \text { for dependencies, } \\
\text { and } 0 \text { for independent countries }\end{array}$ & Bertocchi and Canova (2002) \\
\hline Settler mortality & Settler mortality rate & Acemoglu et al. (2001) \\
\hline Latitude & Absolute value of latitude & $\begin{array}{l}\text { Center for International } \\
\text { Development and The World } \\
\text { Factbook } 2008 \\
\end{array}$ \\
\hline
\end{tabular}




\begin{tabular}{lll}
\hline \hline Landlock & $\begin{array}{l}\text { Binary variable assuming value 1 for } \\
\text { countries with no access to the sea, } 0 \\
\text { otherwise }\end{array}$ & $\begin{array}{l}\text { Center for International } \\
\text { Development }\end{array}$ \\
\hline $\begin{array}{l}\text { Government } \\
\text { effectiveness }\end{array}$ & Government effectiveness index & Kaufmann et al. (2009) \\
\hline Rule of law & Rule of law index & Kaufmann et al. (2009) \\
\hline $\begin{array}{l}\text { Voice and } \\
\text { accountability }\end{array}$ & Voice and accountability index & Kaufmann et al. (2009) \\
\hline \hline
\end{tabular}

